\title{
DEFORESTATION AND MICRO-CLIMATE OF ILORIN AND ITS ENVIRONS
}

\author{
Toluwalope Mubo AGAJA*
}

Department of Geography and Environmental Management, Faculty of Social Sciences, University of Ilorin, P.M.B. 1515, Ilorin, Nigeria, e-mail: specialgel@yahoo.com, agaja.tm@unilorin.edu.ng

Citation: Agaja, T. M. (2019). Deforestation and Micro-Climate of Ilorin and its Environs. Analele Universităţii din Oradea, Seria Geografie, 29(2), 77-85. https://doi.org/10.30892/auog.292108-806

\begin{abstract}
Deforestation is the permanent destruction of forests in order to make the land available for other uses This research is aimed at assessing the level of deforestation and how it affects the micro-climate of Ilorin and its environs with a view to lookup the relationship that exists between deforestation and micro-climate of the study area. The statistical tool to be used are both descriptive (Mean, Tables \& Charts) and inferential statistics (Correlation and regression Analysis). The study reveals that there is a significant relationship between deforestation and micro-climatic variables with $\mathrm{r}^{2}=0.997$ for precipitation, 0.888 for maximum temperature, 0.201 for minimum temperature, 0.432 for solar output, -0.873 and 0.797 for relative humidity and evapo-transpiration respectively. The study concludes that deforestation greatly influences the microclimate of the study area and further recommends enlightening the public through organisation of workshops, seminars, jingles on media as well as enacting of laws that prohibits deforestation.
\end{abstract}

Key words: Deforestation, Climate, Micro-climate, Vegetation Cover

$$
* \quad * \quad * \quad * \quad * \quad *
$$

\section{INTRODUCTION}

Deforestation is the conversion of forested areas to non-forest land for use such as arable land, pasture, urban use, logged area, or wasteland. Deforestation can also be seen as remov al of forests leading to several imbalances ecologically and environmentally and results in declines in habitat and biodiversity (Ahmed and Aliyu, 2019). Urbanization, Mining, Fires, Logging and Agricultural activities are few of the causes of deforestation (Andronache et al., 2019). According to the World Resources Institute (2011), loss of forests contributes between 12 percent and 17 percent of annual global greenhouse gas emissions. Deforestation continues to be a major concern not only in small cities or towns but also on the world scale at large as it appears to be a threat to man and his environment.

Deforestation in itself has been noticed to have accelerated in countries of the tropical region with Nigeria inclusive. Although reliable estimates are not available, it has been put at

\footnotetext{
${ }^{*}$ Corresponding Author
} 
approximately 285,000 ha annually. At this rate of deforestation, $50 \%$ of the country's relatively small forest land area of just 10\% of total land area was eliminated in the year 2015 (Aruofor, 2001).

Forests are of great importance to the environment, it furnishes us with the basic necessities, providing habitats for a variety of species, helps to control and moderate climate, prevent soil erosion and flooding, but despite all these benefits that is obtained from forest ecosystems, the clearing of forests and deforestation brought about by human activities have contributed to the continuous decline of the forests. Deforestation is clearing Earth's forests on a massive scale, often resulting in damage to the quality of the land. Su et al., (2011) reporting (Dove, 1993) indicated that poverty draws people to exploit the products of the tropical forest, clearing and exploiting it for immediate gains. Dolisca et al., (2007) explained that pressures brought about by land tenure system and the growing population sizes are some of the identified causal factors of deforestation.

World Resources Institute (2005) explained that over 11 million hectares of tropical forest are cleared yearly and it is estimated that at present rate of use at least 225 million hectares of tropical forests was cleared in the year 2000, Shifting cultivation is by far the most important cause and it accounts for about $70 \%$ of the total deforestation in the Africa region. Farmers cut forests to provide more room for planting crops or grazing livestock, ranching and development, unsustainable logging for timber, and degradation due to climate change and this impacts people's livelihoods and threatens a wide range of plant and animal species as 46-58 million square miles of forest are lost each year equivalent to 36 football fields every minute (World Wildlife Fund, 2017).

Su et al., (2011) indicated that poverty draws people to exploit the products of the tropical forest, clearing and exploiting it for immediate gains. Dolisca et al., (2007) explained that pressures brought about by land tenure system and the growing population sizes are some of the identified causal factors of deforestation. According to Geist and Lambin (2002), demographic, institutional, cultural factors, economic and technological policy all contribute to the underlying driving forces of deforestation.

Urban and residential area expansion cause significant forest loss, both in the consumption of building materials and as a source of land. With the rise of the need to develop, forested areas are quick to be depopulated to provide logs for man's construction, and a host of other amenities they could derive from the environment (Jacob et al., 2015). These changes cause urban regions to become warmer than their rural surroundings, forming an "island" of higher temperatures in the landscape (EPA, 2017). Therefore, the heat tends to spread to other parts of the city, affecting its microclimate. Vegetation covers serving as carbon sinks i.e. they help to absorb the excess carbon dioxide in the atmosphere are cut down leading to excess carbon dioxide in the atmosphere which in turn causes excessive warming of the surrounding (Royal Meteorological Society, 2017). As rates of deforestation climb and shifts in local climate become more pronounced, the need to understand the relationship between forest cover change and temperature will become more urgent. The more forests we clear, the more we increase risks for food production due to changes in temperature (Field et al., 2012).

\section{THE STUDY AREA}

Ilorin is located on latitudes $8^{\circ} 24^{\prime}$ and $8^{\circ} 36^{\prime}$ North of the equator and longitudes $4^{\circ} 10^{\prime}$ and $4^{\circ} 36^{\prime}$ East of the Greenwich meridian (figure 1). It has an area of about $468 \mathrm{~km}^{2}$. It is $200 \mathrm{~km}$ from Abeokuta, $512 \mathrm{~km}$ from Sokoto, $574 \mathrm{~km}$ from Calabar, $1013 \mathrm{~km}$ from Maiduguri and $494 \mathrm{~km}$ from Aba.

Ilorin experiences humid tropical climate characterized by wet and dry seasons (Olaniran, 2002). The wet season commences towards the ending of March and ends in October. The dry season starts November and spans to February. The dry season in Ilorin is characterized with dusty wind from the northern part of Nigeria referred to as the Harmattan and hot temperature which extend from November to March. The wet season is characterized with high humidity extending from April through November, extremely high temperatures is usually experienced between February and April which usually exceed $30^{\circ} \mathrm{C}$ (Jacob et al., 2015). According to Olaniran, (2002) the mean annual total rainfall in Ilorin is $1200 \mathrm{~mm}$. The temperature of Ilorin 
ranges from $33{ }^{\circ} \mathrm{C}$ to $35^{\circ} \mathrm{C}$ from November to January while from February to April; the value ranges between $34{ }^{\circ} \mathrm{C}$ to $37{ }^{\circ} \mathrm{C}$. The climate of Ilorin supports the growing of tall grass vegetation dotted with medium-sized trees.

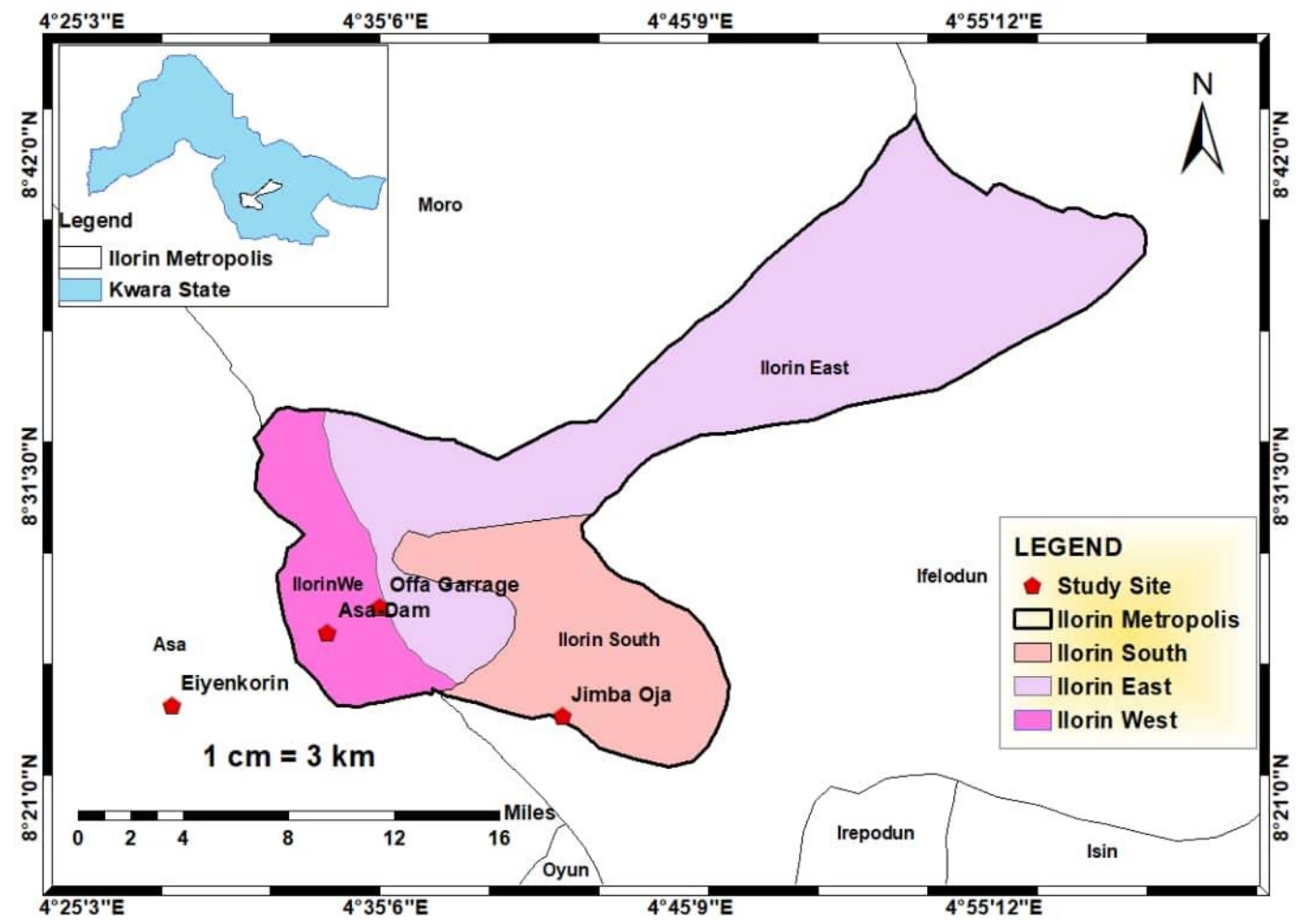

Figure 1. Map of Ilorin Metropolis

Source: Adopted from Kwara State Survey (2018)

Urbanization process is fast replacing the Guinea savannah vegetation in the city with artificial (paved) surfaces with consequent effect on runoff generation, hence, frequent occurrence of flooding (Iroye, 2017), sediments yield (Jimoh, 1999) and erosion (Jimoh, 2000). The soil in Ilorin is formed under the grassland savannah cover and belong to the soil group called Ferruginous soil. This is an ideal soil for the growing of crops such as yam, cassava, and maize, among others. This type of soil yields readily to the agents of denudation when exposed and not protected by vegetation cover.

The prominent land form is Sobi Hill. Ilorin is underlain by Precambrian of basement complex which are neither porous nor permeable except in places where they have been deeply weathered or zones of weakness. Large area of the town is also underlain by sedimentary rock, which contains both primary and secondary laterites and alluvial deposits.

The major rivers are Asa, Agba, Alalubosa, Okun, Osere and Aluko. Some of these rivers drain into river Niger or river Asa (Oyegun, 1986). The drainage system of Ilorin is dendritic in pattern due to its characteristics. The most important river is Asa River which flows in southnorthern direction. Asa River occupies a fairly wide valley and goes a long way to divide Ilorin into two parts namely the Eastern and the western part.

The population of Ilorin as at 2006 census was put at 777,667 (Federal Republic of Nigeria Official Gazette, 2009). Majority of the inhabitants are Yoruba, Hausa and very few Igbo's. Bulk of the land area is used for commercial and residential purpose; small and large-scale industries 
characterize most its environment. The land use of Ilorin some years ago used to be majorly agriculture and forested areas with a few built up areas. The emergence of urbanisation has brought about decrease in the forested areas over time paving way for more residential areas, industries, schools etc. due to increase in population.

\section{MATERIALS AND METHODS}

The data used for this research was gotten from satellite images showing the rate of deforestation in Ilorin for about 30 years. The satellite images were gotten from Landsat, and some information's on methods for the extraction of satellite image data are presented in Table 1.

Table 1. Shows the methods of extraction of satellite image data

Source: Authors computation, 2018

\begin{tabular}{|l|l|l|c|}
\hline \multicolumn{2}{|c|}{ Data } & \multicolumn{1}{c|}{ Resolution } & Source \\
\hline \multirow{4}{*}{ Landsat } & TM 1991 & $60 \mathrm{~m}$ & \\
\cline { 2 - 3 } & TM 1998 & $30 \mathrm{~m}$ & \multirow{2}{*}{$\begin{array}{c}\text { Global Land cover facility / } \\
\text { European Space Agency }\end{array}$} \\
\cline { 2 - 3 } & ETM+ 2003 & $30 \mathrm{~m}(15 \mathrm{~m}$ panchromatic $)$ & \\
\cline { 2 - 3 } & ETM+ 2013 & $15 \mathrm{~m}(10 \mathrm{~m}$ panchromatic $)$ & \\
\cline { 2 - 3 } & OLI 2018 & $15 \mathrm{~m}(10 \mathrm{~m}$ panchromatic $)$ & \\
\hline
\end{tabular}

The steps carried out are Image Pre-processing (Image normalization, Image sub-setting, Image pan-sharpening, Digital Number (DN) to Reflectance Conversion), Image Classification and Feature Extraction (Train signatures, Image segmentation, Support vector machine classification), Estimating Evapotranspiration, and Interpolating Climatic variables. Four satellite images are used for this research. Each satellite images were taken at intervals. The intervals are between 1991-1998, 1998-2003, 2003-2013, and 2013-2018. Descriptive statistics used were Mean, frequency distribution tables and bar charts and correlation matrix analysis were used to determine the relationship between deforestation and the microclimate of the Ilorin.

\section{RESULT AND DISCUSSION}

Ilorin had smaller built-up areas which was just at the centre of the city in 1991. Though the built was gradually spreading into forested areas. The forested areas, marshlands, grasslands and farm beds still had much of the landmass (figure 2). Since the built-up areas and the bare surfaces are smaller, with more vegetation, the temperature at that time was cooler since the urban heat island effect was low. The vegetation affects the micro-climate on $\mathrm{d}$ long run mostly through evapotranspiration and albedo (Royal Meteorological Society, 2017).

In the 1998 image, built-up areas have extended towards the forested areas, grasslands/farmlands, and marshlands/streambed. This is due to the expansion of the city because of increase in population. Also, the bare surfaces have increased leading to increase in temperature during this time. The changes in the size of built up areas, bare surfaces, forested areas, grasslands, marshlands and waterbodies are almost negligible compared to figure 3 in 1991.

The built-up and the bare surface areas have eaten deep into the forested areas by 2003 . Urbanization is a major factor here, because the population in the city has greatly increased, more houses, schools and even commercial centres have been built (Figure 4). The forested areas, marshlands, and grasslands have paved way for more built-up and bare surfaced areas. Deforestation has greatly occurred; large number of trees has been cut down. When this happens, $\mathrm{CO}_{2}$ is released in large amounts to the atmosphere causing excessive warming in the city. Since urbanization is at its peak, the urban heat island effect is inevitable (World Wildlife Fund, 2017). 


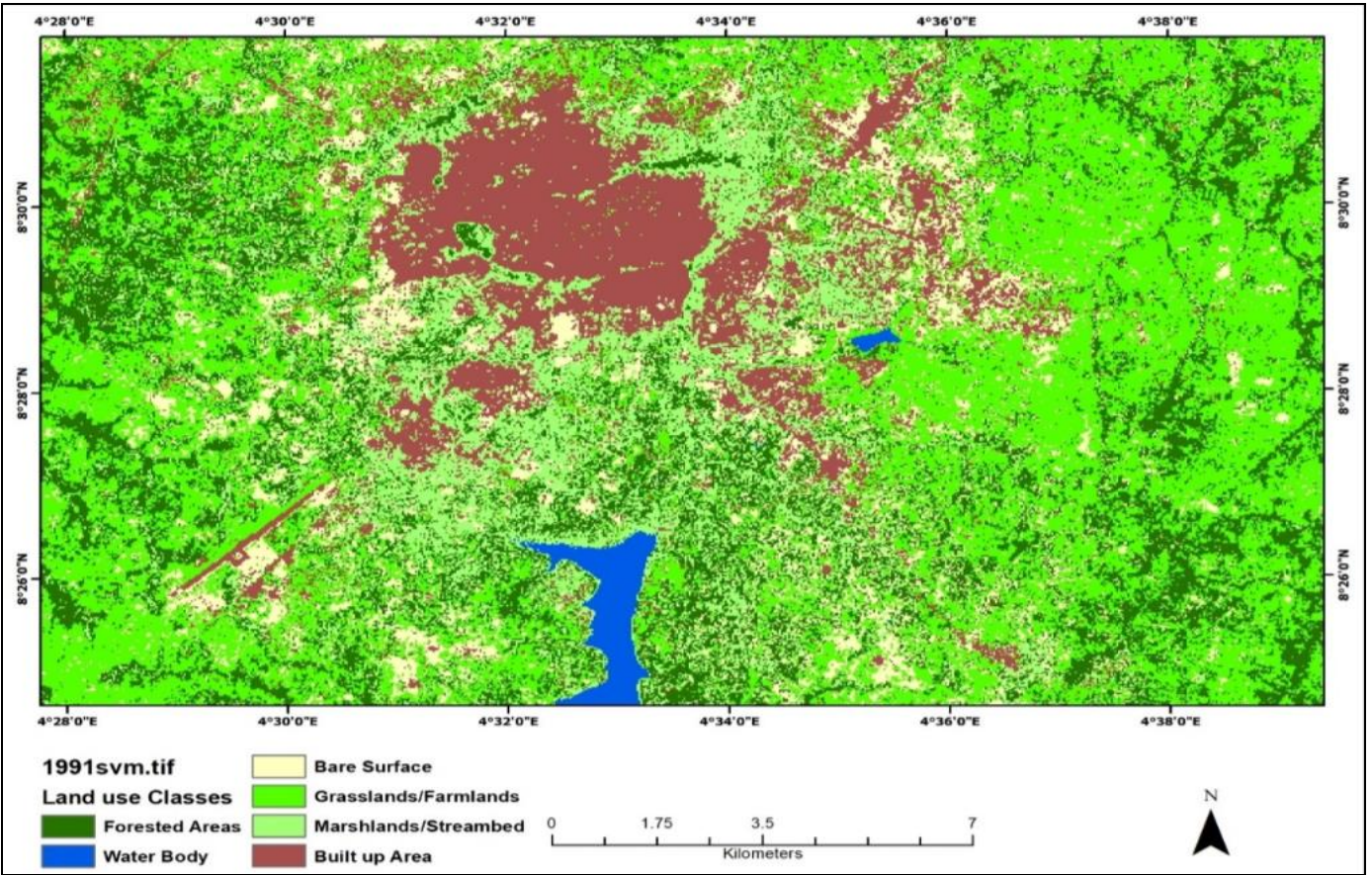

Figure 2. Rate of deforestation in 1991 Source: Landsat Images, 2018

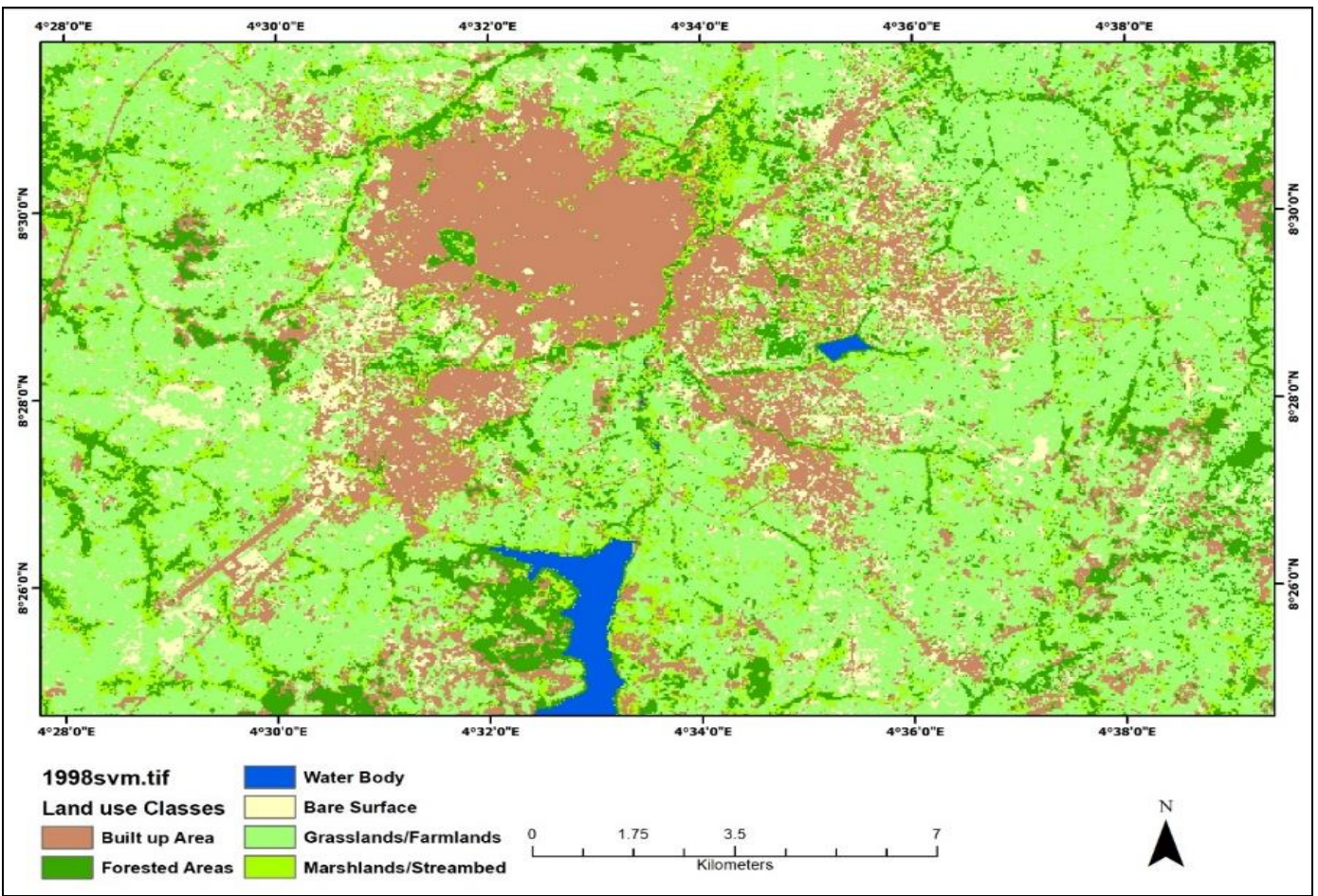

Figure 3. Shows the land use in Ilorin in 1998 Source: Landsat Images, 2018 


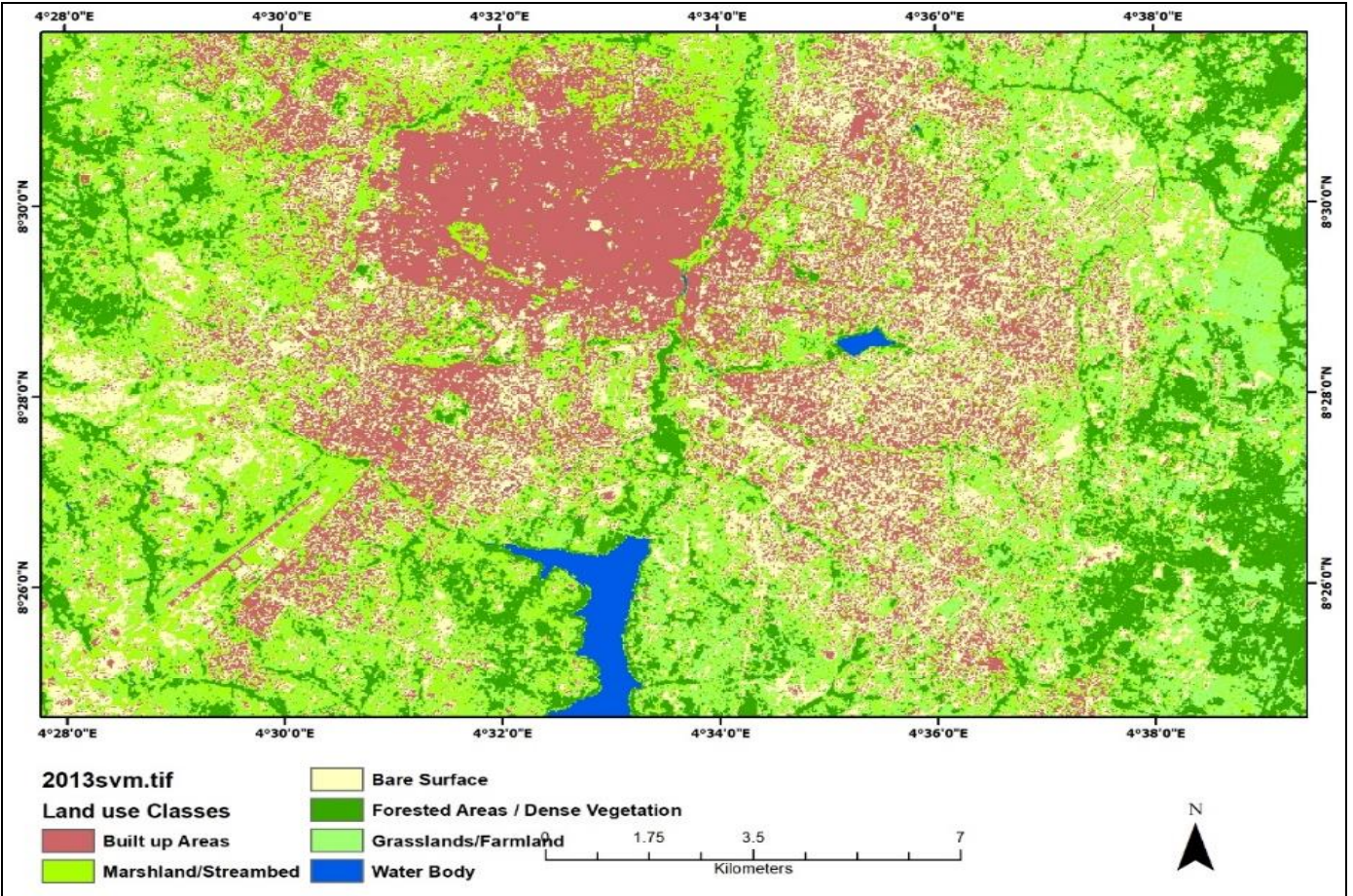

Figure 4. Rate of land use in Ilorin in 2003 Source. Landsat Images, 2018

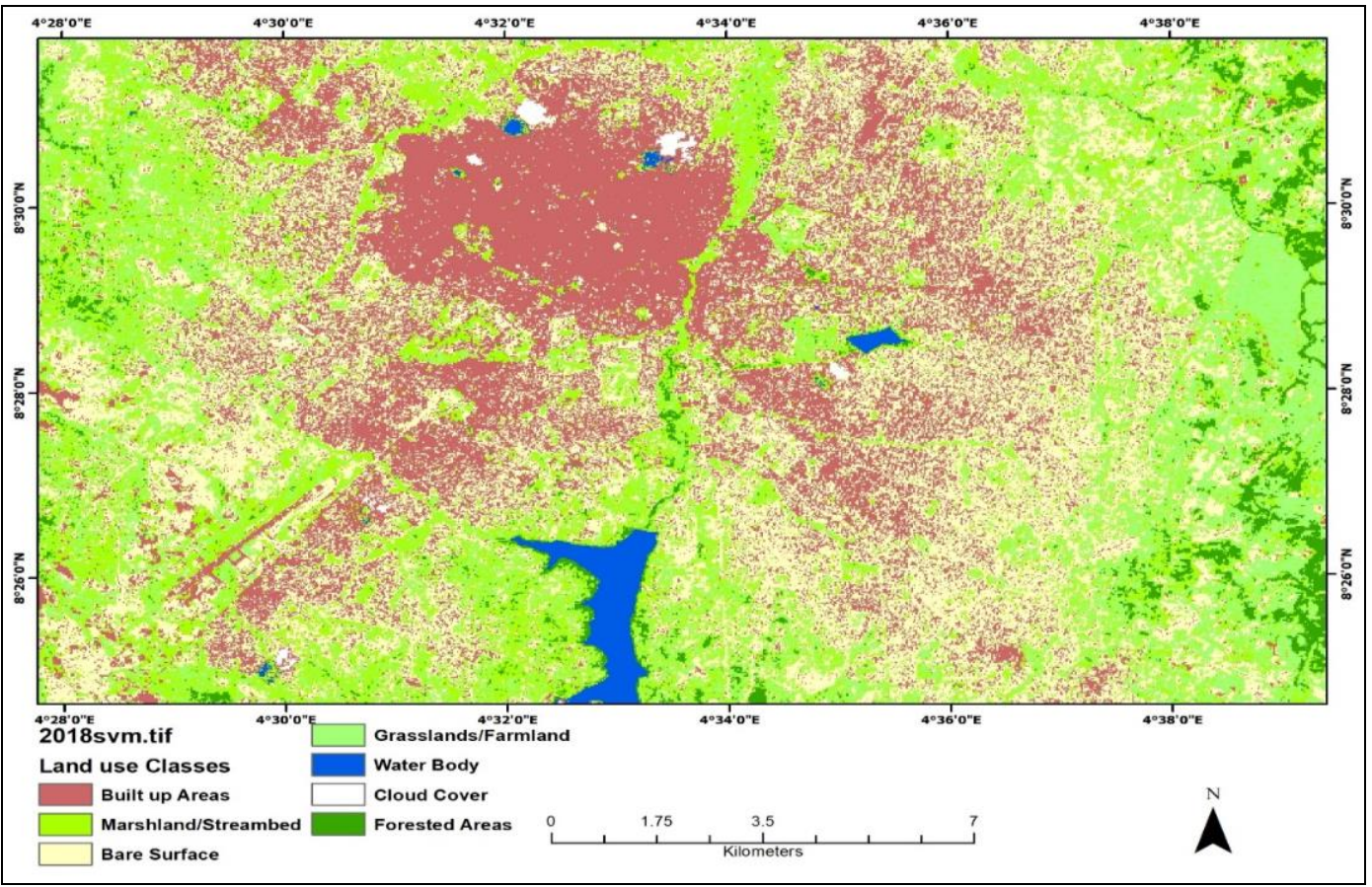

Figure 5. Showing the land use of Ilorin in 2018 Source. Landsat Images, 2018 
There has being a great expansion of the city, and only very few patches of forested areas, marshlands and grasslands left. Gradually, the built-up areas and bare surfaces has expanded and is still expanding till date as shown in figure 5. Forested areas have largely depreciated implying that with the current trend of deforestation, there will be little or no vegetation cover in about two decades from now. The micro-climate has been greatly affected because high temperature changes due change in land use pattern. This is not farfetched from the works of Jacob et al., (2015) reporting that forest have given way to built-up areas and grassland in most areas between 19722014 in Ilorin. Analysis of land surface temperature which shows an increase in urban land surface temperature was due to reduction of forested areas and grasslands.

\section{DEFORESTATION AND CLIMATIC VARIABLES RELATIONSHIP}

The climatic variables for the months/days of the satellite image was derived from the satellite image while gridded datasets for the period was also used to generate micro-climatic data for the study area. They are Land surface temperature, Evapotranspiration, Temperature, Rainfall, Relative Humidity and Solar Radiation

Table 2. Micro-climatic variables for the study

Source. Authors computation, 2018

\begin{tabular}{|l|l|l|l|l|l|l|l|l|}
\hline Date & $\begin{array}{l}\text { Forested Areas } \\
\mathrm{Km}^{2}\end{array}$ & $\begin{array}{l}\text { Max Temp } \\
{ }^{\circ} \mathrm{C}\end{array}$ & $\begin{array}{l}\text { Min Temp } \\
{ }^{\circ} \mathrm{C}\end{array}$ & $\begin{array}{l}\text { PPT } \\
\mathrm{mm} / \text { day }\end{array}$ & $\begin{array}{l}\text { Wind } \\
\mathrm{m} / \mathrm{s}\end{array}$ & $\begin{array}{l}\mathrm{RH} \\
\mathrm{kPa}\end{array}$ & $\begin{array}{l}\text { Solar } \\
\mathrm{MJ} / \mathrm{m} 2 . \mathrm{day}\end{array}$ & $\begin{array}{l}\text { ET } \\
\mathrm{mm} / \mathrm{day}\end{array}$ \\
\hline $3 / 5 / 1991$ & 134.71 & 42.10 & 22.93 & 0.00 & 2.69 & 54.38 & 12.63 & 36.85 \\
\hline $3 / 20 / 1998$ & 128.6 & 40.90 & 19.94 & 0.00 & 2.07 & 43.22 & 26.14 & 33.20 \\
\hline $3 / 8 / 2003$ & 120.51 & 44.20 & 22.06 & 0.00 & 2.56 & 50.06 & 25.08 & 38.75 \\
\hline $3 / 15 / 2013$ & 124.11 & 46.70 & 23.34 & 0.00 & 3.13 & 47.40 & 25.49 & 41.75 \\
\hline $3 / 5 / 2018$ & 40.64 & 33.80 & 21.41 & 0.42 & 3.01 & 69.60 & 28.20 & 28.65 \\
\hline
\end{tabular}

There was a decrease in the size of the forested area from $134.71 \mathrm{~km}^{2}$ in 1991 to $128.6 \mathrm{~km}^{2}$ in $1998,120.51 \mathrm{~km}^{2}$ in 2003 , a slight increase in 2013 with $124.11 \mathrm{~km}^{2}$ and downward trend in 2018 with $40.64 \mathrm{~km}^{2}$. These changes across the time frame caused for variation in the various climatic variables considered as shown in Table 2.

Table 3. Relationship Deforestation and Micro Climatic Variables Source. Authors computation, 2018

\begin{tabular}{|l|l|l|l|l|l|l|l|l|}
\hline \multicolumn{1}{|c|}{ Variables } & \multicolumn{1}{|c|}{$\begin{array}{c}\text { Deforestation } \\
\text { rate }\end{array}$} & $\begin{array}{c}\text { Max } \\
\text { Temp. }\end{array}$ & $\begin{array}{c}\text { Min } \\
\text { Temp. }\end{array}$ & PPT & Wind & RH & $\begin{array}{c}\text { Solar } \\
\text { Output }\end{array}$ & ET \\
\hline Deforestation & 1 & & & & & & & \\
\hline Max Temp & $0.888^{*}$ & 1 & & & & & & \\
\hline Min Temp & 0.201 & 0.479 & 1 & & & & & \\
\hline PPT & $-0.997^{*}$ & $0.912^{*}$ & 0.204 & 1 & & & & \\
\hline Wind & -0.430 & -0.059 & 0.771 & -0.418 & 1 & & & \\
\hline RH & -0.873 & -0.784 & 0.147 & $-0.887 *$ & 0.587 & 1 & & \\
\hline Solar Output & -0.432 & -0.217 & -0.450 & -0.372 & 0.001 & -0.015 & 1 & \\
\hline ET & 0.797 & $0.976^{*}$ & 0.652 & 0.823 & 0.144 & -0.630 & -0.261 & 1 \\
\hline
\end{tabular}

Table 3 presents the results of the correlation between deforestation and micro climate in the study area. The result shows that the coefficient of correlation for maximum temperature $(0.888 *)$ is positive and significantly related to deforestation; meaning that increase in deforestation leads to increase in maximum temperature. This result is similar to the findings of European Commission's Institute for Environment and Sustainability (ECIES) 2016 showing that 
both global forest cover and land surface temperatures, that forest loss causes an increase in temperature variations in areas of deforestation; which tends to lead to an increase in mean and maximum air temperatures.

Removal of vegetal cover increases reflection of incoming solar radiation which leads to excess energy in the atmosphere resulting to increase in temperature. Furthermore, plants absorb excess carbon in the atmosphere for photosynthesis which reduces carbon which is a greenhouse gas that results to global warming. Removal of plants increases the circulation of carbon in the atmosphere resulting to increase in greenhouse gases causing global warming. Global warming results to increase in maximum temperature in the area. This result is corroborated by Gorte (2010) who stated that forests act as what is called a "carbon sink". Carbon sink is the soaking up of carbon dioxide that would otherwise be free in the atmosphere and contribute to ongoing changes in climate patterns. Deforestation undermines this important carbon sink function (Gorte, 2010).

As indicated in Table 3, the result of Precipitation with coefficient of correlation $\left(-0.997^{*}\right)$ is negative and significant. This implies that there is a significant relationship between deforestation and precipitation. Other results in Table 2 shows that minimum temperature $(0.201)$, wind $(0.430)$ and solar output $(0.432)$ is directly related to deforestation but not at a significant level. This implies that increase in deforestation lead to increase in minimum temperature, wind and solar output. In other vein, relative humidity (-0.873) and Evapotranspiration (-0.797) is inversely related to deforestation; meaning that increase in deforestation leads to a decrease in relative humidity and evapotranspiration.

As deforestation increases in the area, rainfall decreases. Plants contribute to rainfall formation process through evapotranspiration. This result is supported by Field et al., (2012) in their study who revealed that forests absorb more rainwater and transpire it as water vapour later. This phenomenon, called evapotranspiration, causes cooling. These two competing biophysical effects could determine whether at a specific location or during a specific time of the day or season of the year, a forest could cause local cooling or warming and, by extension, whether clearing a forest could leads to decrease in rainfall (Field et al., 2012).

\section{CONCLUSION AND RECOMMENDATION}

In conclusion, there is a significant relationship between deforestation and the microclimate of the Ilorin and the study recommends community participation in the forestry conservation and protection initiatives should be made mandatory. This will encourage these communities to device indigenous methods that will help to stop under and over exploitation of forest. Also, due to the nature and extent of forest destruction, efforts to stop the human activities can be complemented by laws and regulation at governmental and organizational levels. Penalties should also be put in place for violators.

\section{REFERENCES}

Ahmed, Y.A., \& Aliyu, I. (2019). Climate Change Induced Challenges on Deforestation: The Needs to Educe Mitigation Measures in Nigeria. Analele Universităţii din Oradea, Seria Geografie, 29(2), 64-76.

Andronache, I., Marin, M., Fischer, R., Ahammer, H., Radulovic, M., Ciobotaru, A. M., Jelinek, H. F., Di Ieva, A., Pintilii, R.-D., Drăghici, C.-C., Herman, G. V., Nicula, A.-S., Simion, A.-G., Loghin, I.-V., Diaconu D.-C. \& Peptenatu D. (2019). Dynamics of Forest Fragmentation and Connectivity Using Particle and Fractal Analysis. Scientific Reports, 9(1), 1-9.

Aruofor, R, (2001). Forest Sector Outlook Study, FOSA Working Paper 36. FAO. p. 31.

Dolisca, F., McDaniel, J. M., Teeter, L. D., \& Jolly, C. M. (2007). Land tenure, population pressure, and deforestation in Haiti: the case of Forêt des Pins Reserve. Journal of Forest Economics, 13(4), 277-289.

EPA (2017). Heat islands, Available online: www.epa.gov/heat-islands Retrieved 1/07/2018

Federal Republic of Nigeria Official Gazette (2009). Legal Notice on Publication of 2006 Census Final Results.

Field, C. B., Barros, V., Stocker, T. F., \& Dahe, Q. (Eds.). (2012). Managing the risks of extreme events and disasters to advance climate change adaptation: special report of the intergovernmental panel on climate change. Cambridge University Press.

Geist, H. J., \& Lambin, E. F. (2002). Proximate Causes and Underlying Driving Forces of Tropical DeforestationTropical 
forests are disappearing as the result of many pressures, both local and regional, acting in various combinations in different geographical locations. BioScience, 52(2), 143-150.

Gorte, R. W., \& Sheikh, P. V. (2010). Deforestation and Climate change, Congressional Research Service Report Paper 7-5700.

Iroye, K. A. (2017). Correlating pattern of river discharge with degree of urbanization in sub-catchments of River Asa in Ilorin, Nigeria. Ethiopian Journal of Environmental Studies and Management, 10(2), 251-261.

Jacob, D., Joseph, A. K., \& Daramola, E. L. (2015). An Assessment Of The Impact Of Deforestation On climate Change: Case Study Of Ilorin, Kwara State. Journal Presented At The $56^{\text {th }}$ Annual Conference Of Association Of Nigeria Geographers (ANG), Osun State University, Nigeria, 1-5.

Jimoh, H. I. (1999). Effects of run-off on sediment transportation and deposition in Ilorin City. Nigeria. Centre Point Journal, 7(2), 97-100.

Jimoh, H. I., \& Ifabiyi, I. P. (2000). Contemporary issues in environmental studies. Ilorin. Haytee Press and Publishing Co. Ltd.

Kwara State Government (2017). Available online: https://kwarastate.gov.ng/about-kwara-state/. Retrieved 10/12/17.

Olaniran, O. J. (2002). Rainfall anomalies in Nigeria: The contemporary understanding. $55^{\text {th }}$ inaugural lecture, University Press Ilorin.

Oyegun, R. O. (1983). Water Resources in Kwara State. Matanmi and Sons printing and publishing Co. Ltd. Ilorin.

Royal Meteorological Society (2017). Microclimates. Available Online:http://www.metlink.org/secondary/key-stage4/microclimates/Retrieved on 5/07/2018.

Su, G. S., Macawile, J., Villarino, A., Agapito, J., \& Gomez, N. (2011). Recognizing local people's perceptions towards deforestation in Quezon Province, Philippines. Environmental Research Journal, 5(3), 131-135.

World Resources Institute (2005). wri.org/publication/world-resources-2005-wealth-poor. Retrieved 08/20/2018.

World Resources Institutes (2011). wri.org/our-work/project/world-resources-report/world-resources-report-2010-2011. Retrieved 03/03/15

World Wildlife Fund (2012). Available Online: www.worldwildlife.org/species. Retrieved 023/02/2015.

World Wildlife Fund (2013). Available Online: www.worldwildlife.org/species. Retrieved 23/02/2015.

World Wildlife Fund (2017). Forest Habitats. Available online: https://www.worldwildlife.org/habitats/foresthabitat.Retrieved 3/03/2018.

Submitted:

April 22, 2019
Revised:

July 28, 2019
Accepted and published online September 11, 2019 